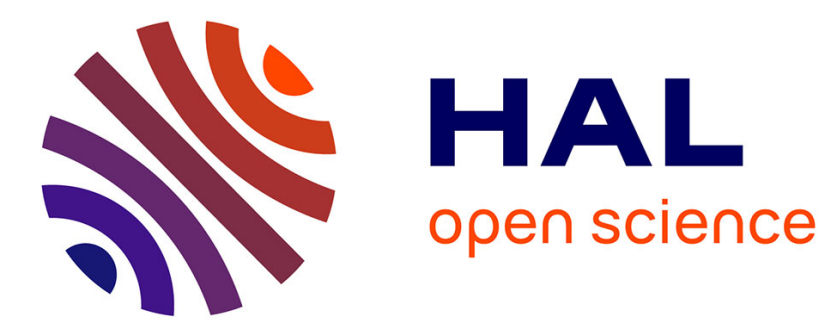

\title{
How to improve Kline and Rosenberg's chain-linked model of innovation: building blocks and diagram-based languages
}

\author{
Jean-Pierre Micaëlli, Joelle Forest, Eric Coatanéa, Galina Medyna
}

\section{To cite this version:}

Jean-Pierre Micaëlli, Joelle Forest, Eric Coatanéa, Galina Medyna. How to improve Kline and Rosenberg's chain-linked model of innovation: building blocks and diagram-based languages. Journal of Innovation Economics \& Management, 2014, 2014(3) (15), pp.59-77. 10.3917/jie.015.0059 . halshs01064736

\section{HAL Id: halshs-01064736 \\ https://shs.hal.science/halshs-01064736}

Submitted on 17 Sep 2014

HAL is a multi-disciplinary open access archive for the deposit and dissemination of scientific research documents, whether they are published or not. The documents may come from teaching and research institutions in France or abroad, or from public or private research centers.
L'archive ouverte pluridisciplinaire HAL, est destinée au dépôt et à la diffusion de documents scientifiques de niveau recherche, publiés ou non, émanant des établissements d'enseignement et de recherche français ou étrangers, des laboratoires publics ou privés. 


\title{
HOW TO IMPROVE KLINE AND ROSENBERG'S CHAIN-LINKED MODEL OF INNOVATION: BUILDING BLOCKS AND DIAGRAM-BASED LANGUAGES
}

\author{
Jean-Pierre MICAËLLI \\ Université de Lyon, Centre de recherche Magelan \\ IAE Lyon, Université Jean Moulin Lyon 3 \\ Centre des Humanités \\ Joëlle FOREST \\ Université de Lyon, INSA Lyon, ITUS Research Team \\ Centre des Humanités \\ Éric COATANÉA \\ Aalto University, School of Engineering \\ Department of Engineering Design and Production \\ Galina MEDYNA \\ Aalto University, School of Engineering \\ Department of Engineering Design and Production
}

\section{INTRODUCTION}

Several theories explain how innovations are produced. One of them assumes that "one does research, research leads to development, development to production, and production to marketing" (Kline, Rosenberg, 1986, p. 285). Innovation production is not only a push process; it is also a hierarchical one (Forest, 2014, p.50). At the top of the ladder, forerunner researchers produce revolutionizing discoveries, inventors embody them, adding to the "pool of technological opportunities" (d'Este et al., 2012, p. 294) that can be exploited by entrepreneurs. Innovation production is a matter of a heroic narrative: the scientific elite conquers frontiers and opens unthinkable opportunities to followers. This tale is based on an optimistic view of science popularized by Vannevar Bush (1890-1974) (Godin, 2005, p. 5). We can then consider this model as a "hierarchical and linear model of innovation" (HLMI). HLMI is coherent with a 'synoptic view of the whole universe' called "hierarchism" (Bunge, 2004, p.35), which assumes that the universe is made up of layers ranging from higher to lower beings (Bunge, 2004, p. 40). A hydraulic analogy can depict innovation production. The more one fills the scientific pool (number of discoveries), the more inventions (number of patents) and innovations (number of new products) will flow out (Forest, 2014, p.52). The more research expenditures and capacity increase, the more inventions and innovations occur. The more research excels, the more major inventions and disruptive innovations are developed (d'Este et al., 2012).

HLMI suffers from "oversimplification" (Rescher, 2013, p. 76), explaining why, since the mid-1980s, different authors have been using the term 'system' to describe how innovations are produced. Christopher Freeman (1921-2010) and his followers conceive innovation production as an idiosyncratic process, revealing the existence of "national innovation systems" (Freeman, Lundvall, 1988). An innovation system is conceived as an empirical entity. It is a network of complementary components (actors, processes, institutions, etc.) 
inducing innovation or some macroeconomic performances (Amable, 2003). This type of empirical and institutional analysis is valuable as it helps to "(...) compare the performances of such systems in different countries, regions and sectors and (...) assess their strengths and limitations so as to guide public policies" (Laperche, 2012, p. 5). Kline and Rosenberg (1986) proposed another systemic model called the "chain-linked model" (CLM). CLM belongs to a synoptic view called "systemism" (Bunge, 2004, p. 53). Systemism conceives a system as an entity (Bunge, 1979, p. 2) describing with "beneficial simplification" (Rescher, 2013, p. 76) a given class of phenomena. A system is abstract and unique ("ontological monism") (Micaëlli et al., 2013). Nevertheless, it is embodied in different instances or occurrences. Thus, an innovation system has always two aspects. It is a functional entity explaining how innovation is always produced (abstract aspect). It has also different instances depicting the way innovation is spatially produced, as mentioned in the abundant literature on innovative milieus, clusters, creative cities, territories, etc. (Geels, 2005, p. 34 ; Hamdouch, 2009, p. 6) (concrete aspect). Systemism is an open framework. We can use it to imagine different scenarios: high versus low research intensity innovation, routine versus breakthrough innovation, methodic versus empirical innovation, local versus global multinational level innovation (Uzunidis, Boutillier, 2012), etc. "Whatever the sector of activity or the spatial level considered (...) knowledge and innovation processes constitute multidimensional, complex and dynamic systems involving a wide range of interdependent agents and forms of interaction", Hamdouch and Moulaert wrote (2006, p. 25).

This article does not focus on the different mentioned instances or occurrences of innovation systems but rather assumes that an innovation system exists as an entity and can be analyzed as such. Thus, systemism highlights four main generic features of a system. First, it has "(...) $a$ definite composition, a definite environment, (...) a definite structure" (Bunge, 1979, p. 4). The structure of a system is usually considered as "semi-decomposable" (Simon, 1997). Secondly, the causality that explains its behavior is not linear but rather circular. "System dynamics" describes and simulates circular causal loops occurring in a system of any kind (Forrester, 1967). Third, systemism assumes that our knowledge about the Universe is also a system (Bunge, 2004, p. 56). Lastly, systemism uses diagrams to depict the system under study.

This article focuses on CLM. Although an academic consensus exists about the value of this model (Godin, 2005, p. 4; Forest, 2014, p. 56), the authors propose that it can be improved to be more coherent with its systemic bases. In order to achieve this, an innovation system should be conceived as an association of three building blocks. The first building block is an actor-focused module. It is a pattern encapsulating innovation actors with volition, abilities, and mutual awareness, who implement innovation-related processes. The second building block is an interactions-focused module. It encapsulates "integrative elements" (Bonjour, Micäelli, 2010) such as institutional nodes and public repositories (syn. pools, stocks). The third building block contains the set of indicators related to innovativeness. Further, after the definition of these three building blocks, the authors depict an innovation system by using different engineering diagram-based languages. Although an innovation system is not a technical entity, the use of these languages is relevant as it dramatically augments the set of entities and relations used in modeling.

This article is structured as follows. Section 1 covers CLM's systemic bases. Section 2 presents the building blocks that facilitate an innovation system modeling. Section 3 illustrates how different engineering diagram-based languages can be used to depict an innovation system. The conclusion discusses the obtained results and the limitations of the 
proposed improvement to CLM, especially those concerning the dynamic aspects of an innovation system.

\section{CLM AS A SYSTEMIC INNOVATION MODEL}

Kline and Rosenberg describe an innovation system as associating a "potential market" expected by entrepreneurs, a set of specialized activities occurring in firms (design, test, production, distribution, etc.) or in public institutions (research), and an accessible stock of knowledge. Activities are represented by boxes that can be opened to detail their content. Some of them depict specialized activities (research, design, produce, etc.), while the box called "knowledge" is an "integrative element" (Bonjour, Micaëlli, 2010) called a pool. This repository interacts with all other components of an innovation system. The interrelations between the boxes are "flow paths of information and cooperation" and they can be linear or iterative ("loops") (Kline, Rosenberg, 1986, p. 290). Some of them are continuous, while others are event-based or conditional. They depend on specific events (market signal inducing innovators' expectations and projects) or premises (if innovators need more knowledge then they pick up data from the stock of knowledge). Some flows are shortcuts, i.e. "direct link to and from research form problems in invention and design" (Kline, Rosenberg, 1986, p. 290). In CLM, innovation is both a push-pull process and a top-down and bottom-up process. Figure 1 displays a representation of CLM (Kline, Rosenberg, 1986, p. 290). This figure shows that CLM is based on a rudimentary diagram-based language.

Figure 1 - Kline \& Rosenberg's Chained-Linked Model (CLM) (1986)

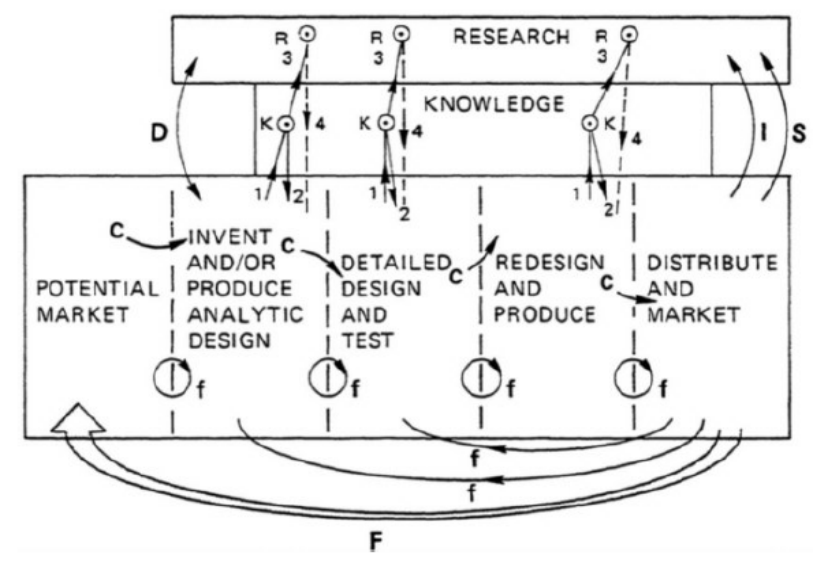

FIGURE 3 Chain-linked model showing flow paths of information and cooperation. Symbols on arrows: $\mathbf{C}=$ central-chain-of-innovation; $\mathbf{f}=$ feedback loops; $\mathbf{F}=$ particularly important feedback.

K-R: Links through knowledge to research and return paths. If problem solved at node $\mathrm{K}$, link 3 to $\mathrm{R}$ not activated. Return from research (link 4) is problematic-therefore dashed line.

D: Direct link to and from research from problems in invention and design.

I: Support of scientific research by instruments, machines, tools, and procedures of technology.

S: Support of research in sciences underlying product area to gain information directly and by monitoring outside work. The information obtained may apply anywhere along the chain.

CLM can be used for various innovation scenarios. In an entrepreneurial tale, Hi Tech entrepreneurs would make the F-Relation effective. They initiate collaborations with research to synchronously develop innovations, inventions, and knowledge. Other combinations of blocks can lead to many other narratives. Lastly, innovativeness depends on the way the components of an innovation system interact. 
CLM has a greater expressive richness than HLMI. Nevertheless, CLM has weaknesses that can be pointed out.

Environmental issues - In systemism, any system under study interacts with an external environment. While we recognize CLM as valid, what is the external environment of an innovation system? This model does not describe it. However, theorists of the national innovation system emphasizes that this environment may be constituted of institutions (values, habits, working rules, etc.) and specific enablers: legal system, political system, educational system, infrastructures, etc (Freeman, Lundvall, 1988 ; Amable, 2002 ; Forest, 2014, p. 56). Moreover, the final innovative result is not represented in CLM, making it difficult to understand the coevolution between the innovative outcome and the innovation process (Geels, 2005, p. 63). In the end, CLM seems to depict an innovation system as a selfsufficient 'individual' who has no relationship with 'alters' (Forest, 2014, p. 56).

Structural issues - Kline and Rosenberg do not consider how innovation systems of different scales or located in different places interact. Other issues of CLM concern the internal structure (endostructure) of an innovation system. Who are the actors who perform innovation-focused activities? Moreover, is a single box labeled as "knowledge" sufficient to describe the set of repositories on which innovation is based? Is it possible to imagine other pools? We can mention the intellectual property rules, financing inducements, etc.

Dynamics issues - CLM describes the set of activities and flows involved in an innovation process. Nevertheless, is this model valuable to describe the long-term evolution of an innovation system? There is no clear answer to this. In contrast, HLMI implicitly assumes that there is an inexorable limit to innovation. If we admit that scientific progress is bounded as "the cost of scientific inquiry raises faster than the [epistemic] returns from it" (Rescher, 1978, p. 2), then inexorability research will produce fewer and fewer inventions and, thus, fewer and fewer innovations. This means that an innovation system is stationary, which is a paradoxical statement when considering the optimistic bases of HLMI (Godin, 2005, p. 4).

Epistemic issues - Lastly, is it sufficient to use a single diagram to depict an innovation system? The original CLM was produced in the mid-1980s. Since then, diagram-based languages have been developed allowing both broader and more rigorous system modeling.

In order to address these issues, this article proposes to revisit CLM by deepening the systemic framework presented above. The authors first suggest enriching the set of entities a systemic innovation model should integrate, before depicting it with different engineering diagram-based languages.

\section{INNOVATION SYSTEM BUILDING BLOCKS}

The first step of systemic modeling consists in bounding the system under study. In the case of an innovation system, the system under study can be considered to be part of a wider system called 'society'. This means that the system under study provides a specific service (innovation production) and interacts with an "institutional framework" (Hamdouch, Moulaert, 2006, p. 41) and infrastructures. Some of these external entities can be considered as innovation enablers. The inclusive relation between an innovation system and society 
explains the fact that it is possible to instantiate it to a given territory or a historical period. An innovation system can be then circumscribed, but it cannot be considered as a self-sufficient entity (Forest, 2014, p.56).

Once the external environment of the system under study is identified, its internal structure must be specified (Bunge, 2004, p. 53). One of the difficulties encountered in systemism concerns the management of the structural complexity. It can be addressed using a heuristic that considers a system as a "semi-decomposable" structure (Simon, 1997). Its "endostructure" (Bunge, 2004, p. 54) can be broken down into separate modules or blocks covering several layers, including the complete system, its sub-systems, the derived sub-subsystems, etc. (Geels, 2005, p. 32). Its "exostructure" can be considered as its meta-system (Bunge, 2004, p. 54). This stratification based on "composite aggregation (i.e., a whole/part relationship)" (OMG, 2011a, p.113) is coherent with hierarchism. It allows top-down approaches of innovation. The modules or the blocks of an innovation system can be also associated. This last pattern is coherent with "atomism" (Bunge, 2004, p. 53), i.e. a synoptic view assuming that every phenomenon is produced by the random interactions of atoms.

Systemism usually considers a set of modules as building blocks. In the case of an innovation system modeling, the authors suggest defining at least three building blocks.

The first block is called an actor-focused building block. It is a pattern associating an actor (what is his role or contribution to the innovation?) and processes describing what he does alone (introvert processes) or by taking into account alters or repositories (extrovert processes). The authors suggest conceiving alters-focused extrovert processes as "choreographies" (OMG, 2011b, p. 25). A choreography is defined by a diagram-based language called BPMN (Business Process Modeling Notification) (2006), which is used to design information systems or workflows. A choreography is an entity describing a "procedural contract between interacting participants" (OMG, 2011b, p. 25). In a choreography "activities are interactions that represent a set (1 or more) of message exchanges, which involves two or more participants. In addition, unlike a normal process, there is no controller, responsible entity or observer of the process" (OMG, 2011b, p. 25).

The second building block contains the integrative elements of an innovation system such as institutional nodes allowing transactions between actors, and public repositories supporting these nodes.

The third building block concerns innovativeness, which is the global performance of an innovation system.

This way of thinking differs from Kline and Rosenberg's as it suggests exploding the boxes of the model instead of integrating research and the central chain of innovation in a single box as done in CLM. With the proposed approach the structure of an innovation system becomes modular. We can extend the set of blocks without modifying the core of the structure. In order to illustrate the three building blocks described above, this article considers a very simple innovation system associating an innovator, a competitor, a researcher, an inventor, a user, a standard maker, and a political or financial support, i.e. a "supportive institution" (Hamdouch, Moulaert, 2006, p. 26) (Table 1). 
Table 1 - Actors of an Innovation System

\begin{tabular}{|c|c|c|c|}
\hline & & Actor & Role: transforming... \\
\hline $\begin{array}{l}\text { System under } \\
\text { study }\end{array}$ & $\begin{array}{l}\text { Innovation } \\
\text { development }\end{array}$ & Innovator & $\begin{array}{l}\text {... a potential need into a new product launched on } \\
\text { the market. }\end{array}$ \\
\hline \multirow{5}{*}{ Enablers } & Invention & Inventor & $\begin{array}{l}\text {... a perceived need into a new technical concept } \\
\text { that can be patented. }\end{array}$ \\
\hline & Use & User & $\begin{array}{l}\text {... a felt need into a purchased and an adopted new } \\
\text { product. }\end{array}$ \\
\hline & Research & Researcher & $\begin{array}{l}\text {.. a worrying question related to a state of doubt, } \\
\text { ignorance, etc., into true knowledge. }\end{array}$ \\
\hline & Standardization & $\begin{array}{l}\text { Standard } \\
\text { Maker }\end{array}$ & ... an informal practice into a rationalized one. \\
\hline & Support & Support & $\begin{array}{l}\text {... political goal or a social value into incentives } \\
\text { for innovation. }\end{array}$ \\
\hline $\begin{array}{l}\text { Antagonistic } \\
\text { entity }\end{array}$ & Competition & Competitor & ....an innovation into a potential surrogate product. \\
\hline
\end{tabular}

In systemic models, an association between blocks can be deterministic or conditional. In the present case, the transactions between the innovator and the user are deterministic. That means that they always occur in innovation processes. The transactions between innovation development, competition, research, standardization and support are conditional. An innovator can develop an innovation without collaborating with inventors or researchers, using creative methods, and benefiting from public subsidies. If a systemic model contains a large number of conditions, then various innovation tales can be told. The associations between building blocks can help diagnose how an innovation system performs or fails (Woolthuis et al., 2010, p. 611). If one connected block fails, e.g. design (Forest, 2014, p.54), then the whole innovation process will not be effective. Lastly, an association helps us understand how the blocks interact. In the present case, mutual awareness and capability are key properties of innovation actors. An innovation system cannot perform if the actors are not mutually aware or if they cannot access institutional nodes or repositories.

Once the actor-focused building blocks defined, the content of all processes an actor performs should be clarified. BPMN is relevant for this process elicitation. We can only consider the following entities: "flow objects", which defines the behavior of any process (events, activities, gateways), "connecting objects" (sequence flows, message flows, associations), and "swim lanes" grouping the previous elements (OMG, 2011b, p. 27-28). Table 2 synthesizes the values taken by these elements in the case of an improved CLM.

Table 2 - Some useful BPMN Entities for Innovation Process Modeling

\begin{tabular}{|c|c|c|c|}
\hline & \multicolumn{3}{|c|}{ Main Entities } \\
\hline & Initial Event & Ending & Main swim lane \\
\hline Innovation development & Expected market opportunity & Launched new product & Innovation \\
\hline Invention & Need under study & New technical concept & Invention \\
\hline Use & Felt need & Adopted product & Adoption \\
\hline Research & Question & True knowledge & Scientific inquiry \\
\hline Standardization & Unsatisfactory practice & Rationalized practice & Codification \\
\hline Support & Claim & Incentives or funds & Support \\
\hline Competition & Launched innovation & Surrogate product & Competition \\
\hline
\end{tabular}


BPMN CLM re-modeling shows the shortcomings of the initial model. First, the CLM item "potential market" should be considered as an event. Second, every actor performs processes because of specific events which are not explained by Kline and Rosenberg. Third, the use of BPMN's "swim lane" means that a process can be divided into stratified sub-processes. For example, innovators must be aware about the potential users' needs, competitors' intents, political opportunities, legal opportunities to protect their innovation (patents, trademarks, etc.). In this way they perform tiers-focused processes (TFP). Innovators also implement organisation-focused processes (OP) with introvert (project management) or extrovert features, e.g. "open innovation" community (Chesbrough, 2003). Innovators can use specific tools (business intelligence, market research, creativity methods, etc.), realizing an introvert process called support process (SP). They must develop the innovation by designing it, producing it, and launching it on the market. This last process can be considered as the core process of innovation development (ID). Thus, the "central chain" of Kline and Rosenberg's model can be depicted as a BPMN's pool combining extrovert and introvert processes (TFP, OP, SP, ID). Some of these processes are routines, e.g. patent deposit. Other are "ad hoc subprocesses" (OMG, 2011b, p. 182). They have creative features such as exploration aspects, synthesis of scattered items, etc.

Moreover, Kline and Rosenberg suggested that knowledge is an important stock of an innovation system. In this work, we identify different specific repositories. Actors can increment these pools, playing the role of driven actors. They can also use these stocks. Table 3 presents the selected private and public repositories.

Table 3 - Innovation System Repositories.

\begin{tabular}{|l|l|l|}
\hline \multicolumn{2}{|l|}{ Repositories } & Content \\
\hline Innovator's private repository & Private data, tacit knowledge, routines, etc. Driven actors: innovators. \\
\hline \multirow{4}{*}{$\begin{array}{l}\text { Public } \\
\text { repositories }\end{array}$} & Inventions & Patents, patterns, etc. Driven actors: inventors. \\
\cline { 2 - 3 } & Products & Products available on the market. Driven actors: users and competitors. \\
\cline { 2 - 3 } & Discoveries & $\begin{array}{l}\text { Question agenda and a set of scientific answers (scientific literature). Driven } \\
\text { actors: researchers. }\end{array}$ \\
\cline { 2 - 3 } & Standards & Public standards. Driven actors: standards makers. \\
\cline { 2 - 3 } & Supports & Innovation-focused incentives. Driven actors: supporters. \\
\hline
\end{tabular}

The expressive power of BPMN is not simply embedded in the set of entities and relations presented above. In addition, as previously noted, BPMN proposes an original entity called "choreography" (OMG, 2011, p. 25). In the case of an innovation system, this means that the central chain can be also modeled as a choreography. It involves different actors (marketing specialists, product designers, process engineers, etc.) who exchange different messages or artifacts (market researches, bills of requirements, prototypes, patents, etc.). On a broader level, the transactions between actors within institutional nodes can also be described as choreographies. Table 4 presents the set of institutional nodes and choreographies taken into account in this work.

Table 4 - Institutional Nodes and Choreographies

\begin{tabular}{|c|c|c|c|c|c|}
\hline \multirow{2}{*}{$\begin{array}{c}\text { Institutional } \\
\text { Node }\end{array}$} & \multicolumn{2}{|c|}{ Actors in relation } & \multirow{2}{*}{$\begin{array}{c}\text { Collective } \\
\text { Activity }\end{array}$} & Initial Event & Ending \\
\cline { 2 - 3 } & Driven Actor & Drive Actor(s) & \\
\hline
\end{tabular}




\begin{tabular}{|l|l|l|l|l|l|} 
Market & Innovator & User, competitor & $\begin{array}{l}\text { Bargaining } \\
\text { products }\end{array}$ & $\begin{array}{l}\text { Expected } \\
\text { market } \\
\text { opportunity }\end{array}$ & $\begin{array}{l}\text { Launched new } \\
\text { product }\end{array}$ \\
\hline $\begin{array}{l}\text { Invention } \\
\text { Agora }\end{array}$ & Inventor & $\begin{array}{l}\text { User, researcher, } \\
\text { innovator }\end{array}$ & Open invention & $\begin{array}{l}\text { Need under } \\
\text { study }\end{array}$ & $\begin{array}{l}\text { New technical } \\
\text { concept }\end{array}$ \\
\hline $\begin{array}{l}\text { Scientific } \\
\text { Agora }\end{array}$ & Researcher & $\begin{array}{l}\text { Supporter, } \\
\text { inventor, } \\
\text { innovator, user, } \\
\text { standard maker }\end{array}$ & Open research & $\begin{array}{l}\text { Worrying } \\
\text { question }\end{array}$ & True knowledge \\
\hline $\begin{array}{l}\text { Political } \\
\text { Agora }\end{array}$ & $\begin{array}{l}\text { Innovation } \\
\text { Supporter }\end{array}$ & $\begin{array}{l}\text { Researcher, } \\
\text { inventor, } \\
\text { innovator, user, } \\
\text { standard maker }\end{array}$ & $\begin{array}{l}\text { linnovation } \\
\text { supports }\end{array}$ & Claim & Incentives \\
\hline $\begin{array}{l}\text { Community } \\
\text { of practice }\end{array}$ & Standard Maker & $\begin{array}{l}\text { Innovator, } \\
\text { inventor, } \\
\text { researcher or } \\
\text { supporter }\end{array}$ & $\begin{array}{l}\text { Innovation } \\
\text { standardization }\end{array}$ & $\begin{array}{l}\text { Unsatisfactory } \\
\text { practice }\end{array}$ & $\begin{array}{l}\text { Rationalized } \\
\text { practice }\end{array}$ \\
\hline
\end{tabular}

The last CLM improvement concerns the way an innovation system is evaluated. In HLMI, innovation research indicators are then necessary and sufficient to measure innovativeness (Forest, 2014, p.51). In systemic models, innovativeness is a holistic performance. It is "derived" into key indicators "allocated" (OMG, 2012, p. 133) to each building block or component of an innovation system Therefore, innovativeness evaluation or explanation is not an easy task. For example, innovativeness depends on actors' capability and maturity level to perform processes. It also depends on actors' communality, i.e. the number and the nature of different actors interacting in choreographies, their proximity (Konsti-Laakso et al., 2012, p. 97). Lastly, innovativeness depends on public repositories accessibility (Chen, Guan, 2011, p. 338).

Following this description of the proposed improvements to CLM, the next section recreates these elements in different engineering diagram-based languages.

\section{DIAGRAM-BASED LANGUAGES FOR INNOVATION SYSTEM MODELLING}

When modeling a technical system, engineers usually start with a black box model. This model bounds the system under study and details its external environment. This environment usually includes actors interacting with the system. In the present case, SysML (System Modeling Language, 2006) "context diagram" (OMG, 2012, p. 158) represents social actors conceiving the innovation system and its enablers (institutional framework, infrastructures) (Figure 2). The label '1..*' means 'one or more'. 'x1:' and ' $\mathrm{x} 2$ :' indicate that two types of interacting entities are taken into account (social actors, enablers). In this "context diagram" (OMG, 2012, p. 158), each social actor has a different view of a unique system. He expects a service provided by the system under study. 


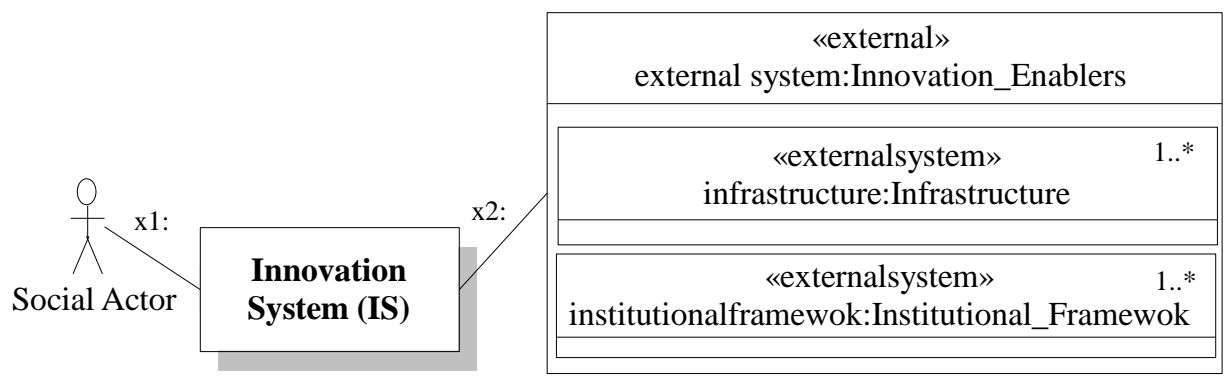

Figure 3 represents a first white box model of an innovation system, i.e. its endostructure. In UML (Unified Modeling Language, 1995) "structure diagram" an association is displayed by a line and a diamond (OMG, 2011a). The cardinality of the relation indicates how many entities are associated, e.g. '2..*' for 'at least two'. Innovation system modeling requires at least two actors (innovator, user), one institutional node (market), and one public repository (products pool). Moreover, an innovation system is always evaluated by its innovativeness. Figure 3 indicates that an innovation system can be decomposed into sub-level innovation systems (reflexive relation). Lines with a white triangle display inheritance relations. For example, an innovation system is a system, innovators or users are actors, etc.

Figure 3 - Innovation System Structure Diagram

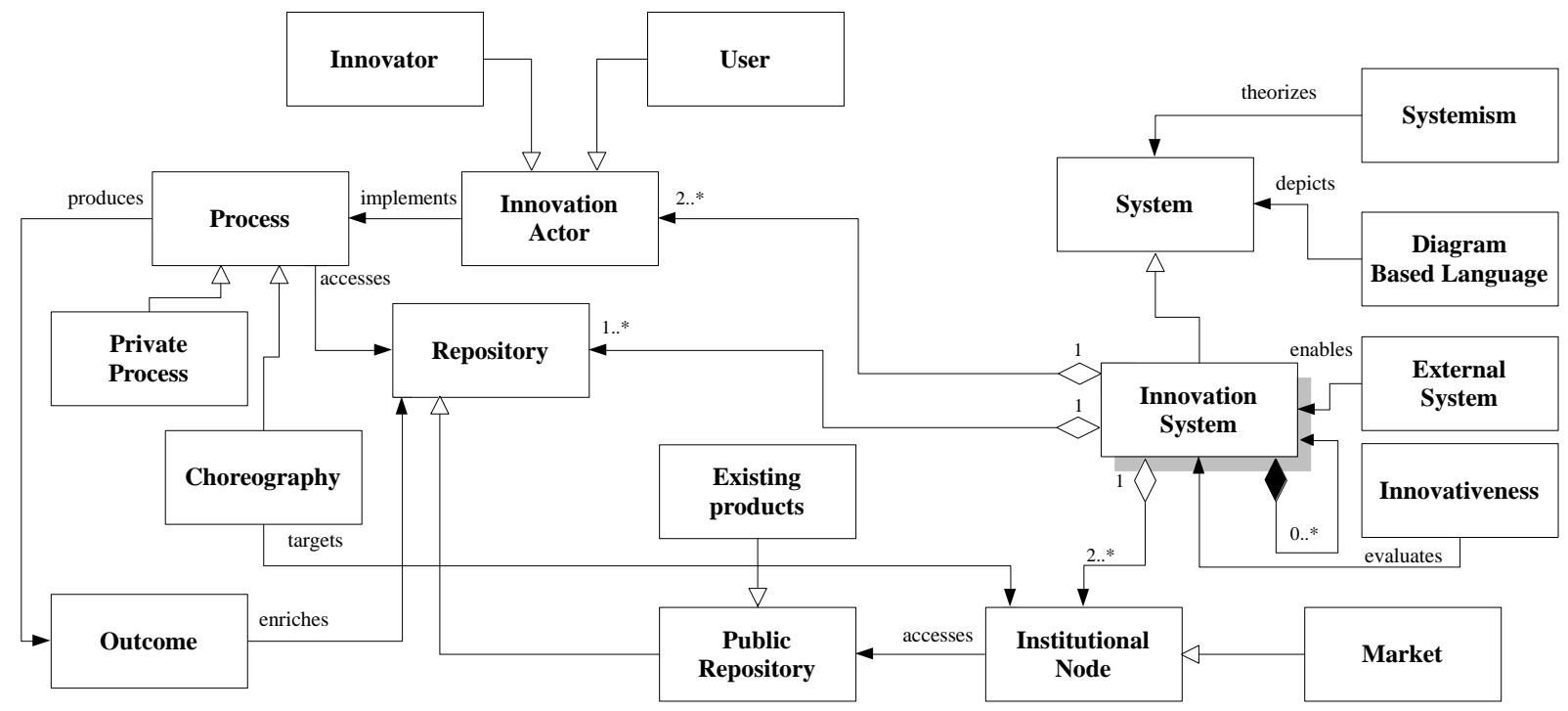

Figure 4 depicts an innovation system map. This map includes instances of the building blocks presented in the previous section of this article. UML, BPMN or SysML are not convenient to depict such a map. The figure is then based on a language called TOGAF (The Open Group Architecture Framework, 1995). The proposed TOGAF "conceptual diagram" includes the set of entities defined Figure 3. It integrates specific TOGAF entities such as inputs of the institutional nodes and entities moving from them to public "repositories" (TOGAF, 2013). If an actor drives a node, the authors suggest that he should be connected through the port at the top of the 'I-block' (TOGAF, 2013) ('I', for input). If an actor is a 
driven actor, then he should be connected through the port at the bottom of the 'I-block'. 'Eblocks'(TOGAF, 2013) describe entities circulating between the institutional node and the public repository. For example, patents circulate from the invention agora to the inventions repository. Inventors are the driven actors of the accumulation of technical concepts or devices occurring in this pool. The target at the bottom right of the figure 4 indicates that the performance of the system under study can be evaluated. Lastly, instances of external systems enabling innovation are represented on the right side of the figure.

Figure 4 - Innovation System Map.

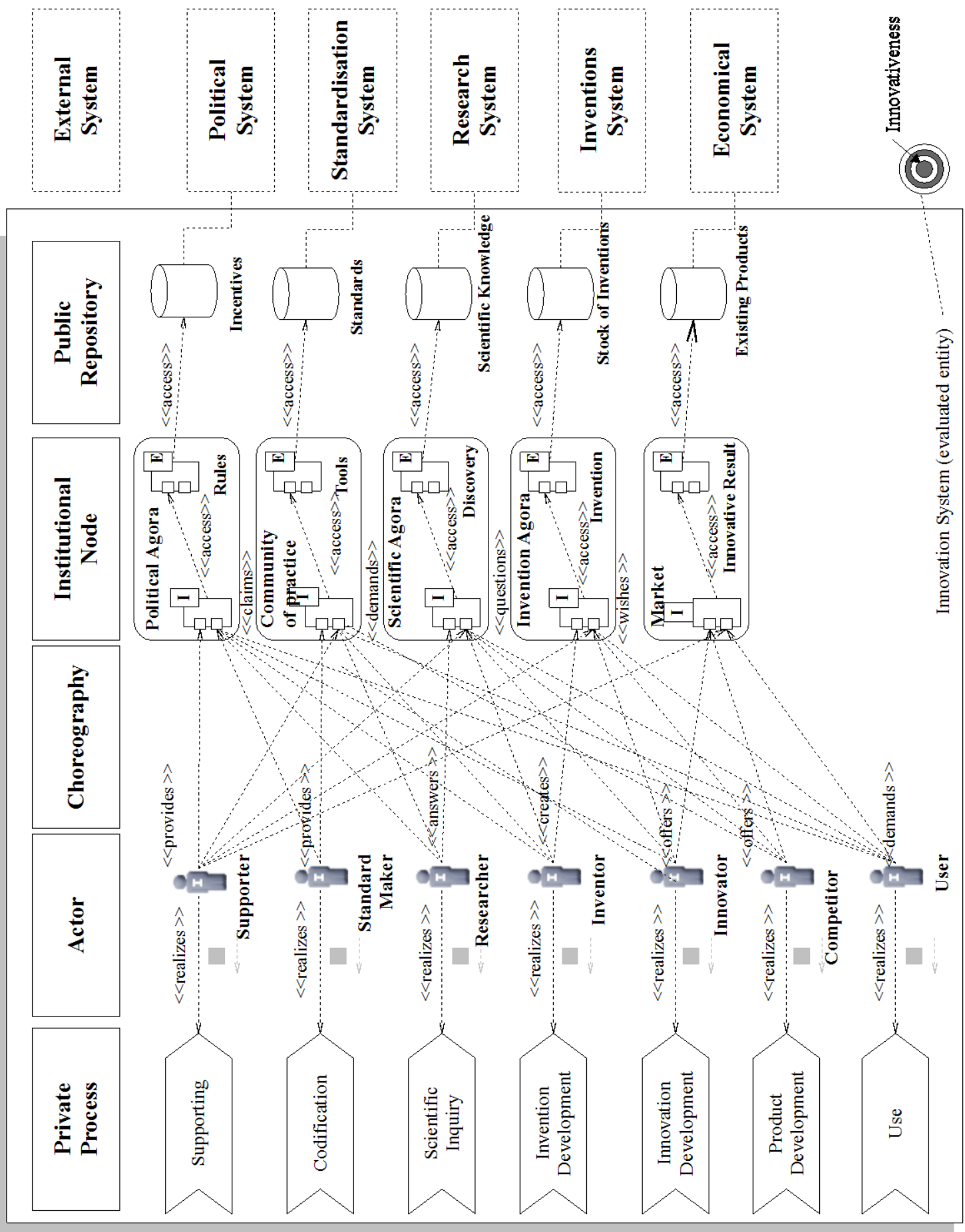


Figure 5 depicts private processes and choreographies occurring in an innovation system. This figure indicates that innovation production requires different actors realizing different processes and thus reacting to different types of events.

Figure 5 - Private Processes and Choreographies

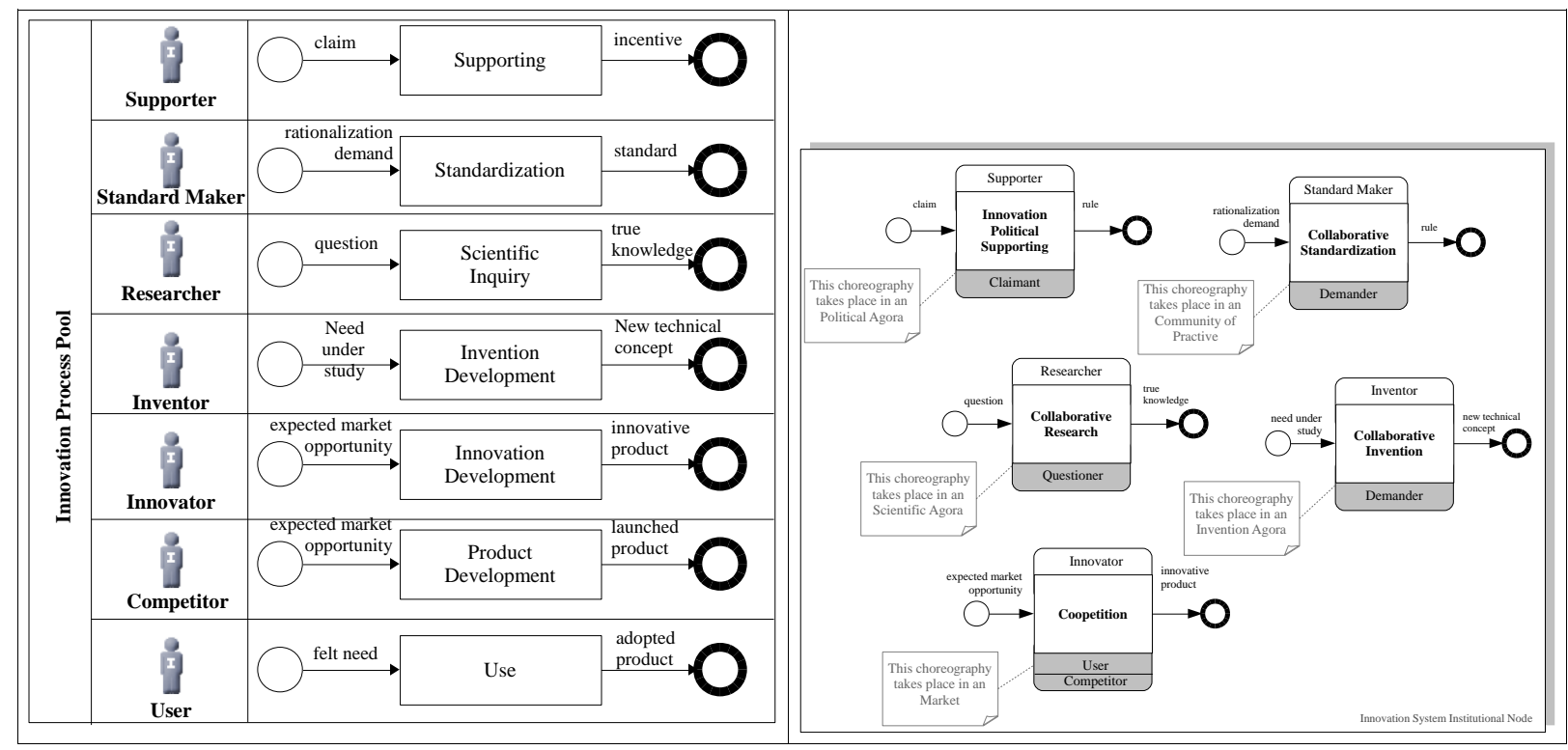

Figure 6 is another BPMN diagram. It depicts a potential swim lane performed by an innovator. Each activity can be detailed into an underlying process. In CLM, the central chain involves different swim lanes, i.e. tiers-focused process (research collaboration) (TFP), organization process (OP) (project or community management), support process (marketing research) (SP), and innovation development process (ID) (market expectation, innovation design, etc.). Underlying processes of the central chain are indicated in gray.

Figure 6 - Innovation Swim Lanes

\begin{tabular}{|c|c|c|c|c|c|c|}
\hline \multirow{2}{*}{ Innovator } & \multirow{2}{*}{ TFP } & $\begin{array}{l}\text { Antagonistic } \\
\text { Processes }\end{array}$ & $\begin{array}{l}\text { Innovation } \\
\text { Protection }\end{array}$ & $\begin{array}{c}\text { Innovation } \\
\text { Competition Manage }\end{array}$ & & \\
\hline & & $\begin{array}{l}\text { Cooperative } \\
\text { Processes }\end{array}$ & $\begin{array}{c}\text { Research } \\
\text { Collaboration }\end{array}$ & $\begin{array}{c}\text { Invention } \\
\text { Collaboration }\end{array}$ & $\begin{array}{l}\text { Innovation } \\
\text { Funding }\end{array}$ & Lobbying \\
\hline \multirow{3}{*}{ 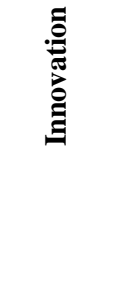 } & OP & $\begin{array}{c}\text { Project } \\
\text { Management }\end{array}$ & $\begin{array}{c}\text { Team } \\
\text { Management }\end{array}$ & $\begin{array}{l}\text { Community } \\
\text { Management }\end{array}$ & & \\
\hline & SP & Use Analysis & $\begin{array}{l}\text { Marketing } \\
\text { Research }\end{array}$ & $\begin{array}{l}\text { Business } \\
\text { Intelligence }\end{array}$ & $\begin{array}{l}\text { Creative Methods } \\
\text { Implementation }\end{array}$ & $\begin{array}{c}\text { IT tools } \\
\text { Implementation }\end{array}$ \\
\hline & ID & $\begin{array}{l}\text { Market Expectation } \\
\text { Conceptualisation }\end{array}$ & $\begin{array}{l}\text { Innovation } \\
\text { Design }\end{array}$ & $\begin{array}{l}\text { Innovation } \\
\text { Making }\end{array}$ & $\begin{array}{l}\text { Innovation } \\
\text { Launching }\end{array}$ & \\
\hline
\end{tabular}

Lastly, Figure 7 presents a structure diagram combining the set of key indicators explaining innovativeness. The relation 'deriveInd' depicts the link between drive and driven indicators. 
For example, 'Innovative Ability' derives from 'Innovativeness'. The indicators can be considered as variables of a structural model explaining why innovativeness succeeds or fails. Well-known causal graphs and the path analysis proposed by Sewall Wright (1899-1988) can be used. A driven indicator is then considered as an explanatory variable ('Innovativeness' is explained by 'Innovative Ability').

Figure 7 - Innovativeness Key Indicators Graph

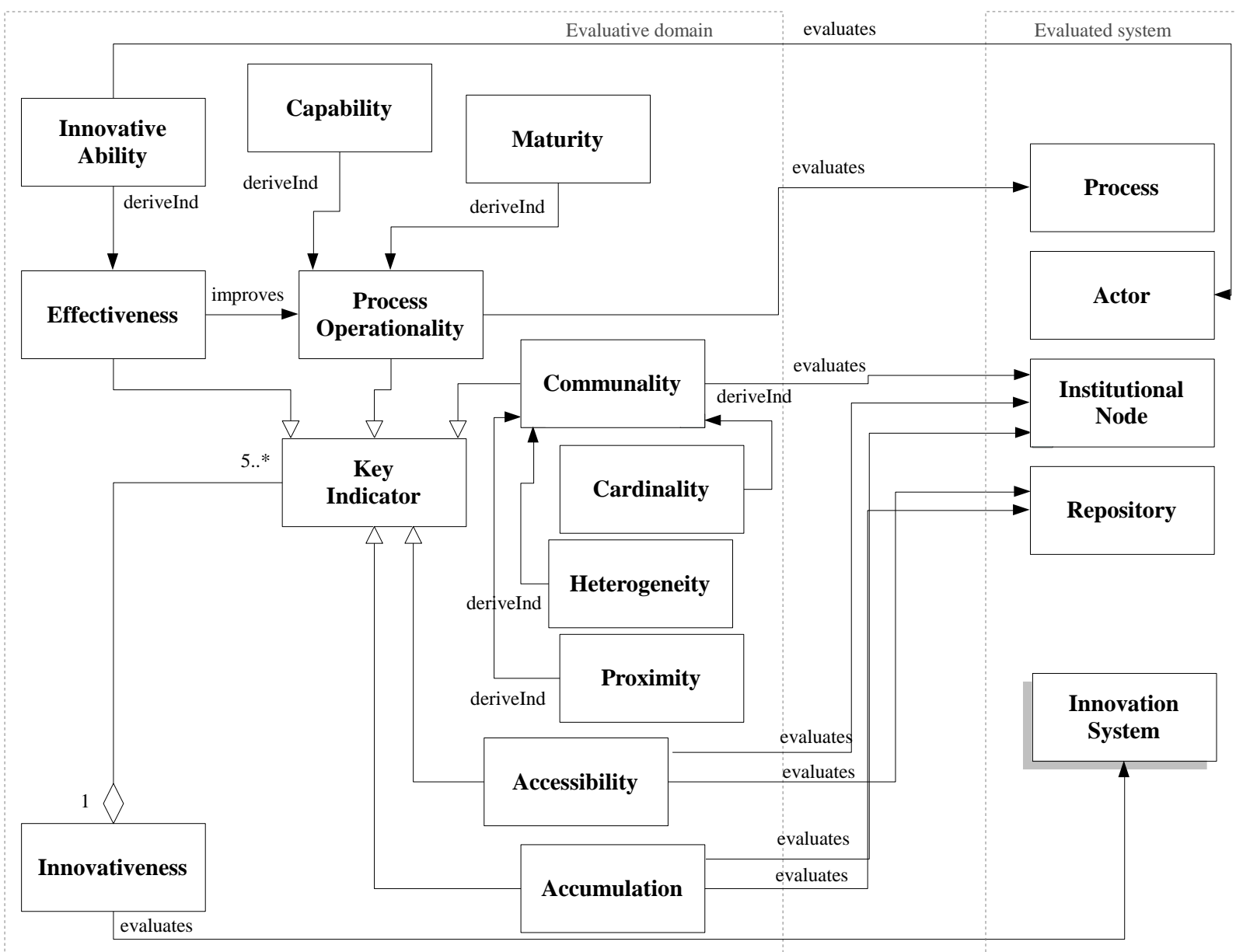

The previous key indicator structure diagram concludes the CLM improvements suggested in this article. They are also listed in Table 5 with indications as to the suggested related engineering diagram-based languages that should be used.

Table 5 - Other Innovation System Diagrams

\section{CONCLUSION}

This article presents a series of incremental improvements of Kline and Rosenberg's chainlinked model (CLM) that aim to make it more coherent with its systemic bases. Thus, this work suggests (1) conceiving an innovation system as an association of building blocks, and 
(2) displaying this system by using diagram-based languages. The proposed improved model enriches the set of viewpoints, entities and relations that can be used to depict an innovation system. Nevertheless, this work has, by far, not exhausted the richness of systemic models. For example, the original and improved CLMs are both structural models. They do not consider the dynamics of an innovation system (long-run evolution, life-cycle, coevolution, etc.).

Systems thinking analyzes dynamics by using two complementary views, logical and temporal. What are the sets of events driving innovation production success or failure? How many arrows and loops do actors realize in sub-processes? On which "branching structures" (Rescher, Urquhart, 1971, p. 70) is innovation based? Indeed, in these structures, as a process goes forward, the set of events driving the current state and the scope of opportunities change. Thus, the dynamics are both deterministic and random. In temporal dynamics, one speaks of moment, duration, period, etc., Physical metrics are used to model the system to answer the following questions: How long does a choreography last? How long does an institutional last? How long does a repository accumulation last? Etc. Overall, the issues relating to the logical and temporal dynamics of an innovation system are extremely complex (Galanakis, 2006).

BPMN provides elements giving a temporal feature to innovation systems. Furthermore, models based on system dynamics can represent the way a whole innovation system performs, evolves, or fails. Activities are then conceived as a control variable regulating flows that are aggregated in the repositories. For example, Samara et al. (2012) suggest an interesting approach to manage such an issue. The authors identify different causal loops explaining the push-pull dynamics of an innovation system. They use different physical variables: R\&D capacity, market share, etc. Dangelico et al (2010) combine classical Forresterian systems dynamics and an agent-approach to model collective behavior occurring in institutional nodes. Such a model is coherent with atomism.

As shown in the incremental improvements introduced, there is no doubt that systemism can extend our understanding of how innovation is produced and the way to depict this complex phenomenon.

\section{REFERENCES}

AMABLE, B. (2002), Les Systèmes d'innovation, In Mustar, P., Penan, H. (eds), Encyclopédie de l'innovation, Paris, F, Economica.

BONJOUR, É., MICAËLLI, J. (2010), Design Core Competence Diagnosis: A Case from the Automotive Industry, IEEE Transaction on Engineering Management, 57, 2, pp. 323-337.

BUNGE, M. (1979), Treatise on Basic Philosophy, Volume 4: A World of Systems, Dordrecht, NL, Reidel.

BUNGE, M. (2004), Matérialisme et Humanisme: Pour surmonter la crise de la pensée, Montréal, PQ, Liber.

CHEN, K., GUAN, J. (2011), Mapping the innovation production process from accumulative advantage to economic outcome: A path modeling approach, Technovation, 31, 7, pp. 336346.

CHESBROUGH, H. (2003), Open Innovation: The New Imperative for Creating and Profiting from Technology, Cambridge, MA, Harvard Business School Press. 
D'ESTE, P., MAHDI, S., NEELY, A., RENTOCCHINI, F. (2012), Inventors and entrepreneurs in academia: What types of skills and experience matter? Technovation, 32, 9-10, pp. 293303.

DANGELICO, R., GARAVELLI, A., PETRUZZELLI, A. (2010), A system dynamics model to analyze technology districts' evolution in a knowledge-basedperspective, Technovation, 30, 4, pp. 142-143.

FOREST, J. (2014), Petite histoire des modèles d'innovation, In : Boutillier, S., Gallaud, D., Forest, J., Laperche, B., Tanguy, C., Temri, L. (eds), Principes d'Économie de l'innovation, Bruxelles, B, Peter Lang, pp. 45-57.

FORRESTER, J. (1967), Principles of Systems, Cambridge, MA, Wright Allen.

FREEMAN, C., LUNDVALL, B. (1988), Small Nations Facing the Technological Revolution, London, UK, Pinter Publishers.

GALANAKIS, K. (2006), Innovation process. Make sense using systems thinking, Technovation, 26, 11, pp. 1222-1232.

GEELS, F. (2005), Technological Transitions and System Innovations: A Co-Evolutionary and Socio-Technical Analysis, Cheltenham, UK, Edward Elgar.

GODIN, B. (2005), The Linear Model of Innovation: The Historical Construction of an Analytical Framework, Project on the History and Sociology of S\&T Statistics, Working Paper, 30, Montreal, CA, CSIIC.

HAMDOUCH, A. (2009) Networking, clustering and innovation dynamics in the global economy: general presentation, Journal of Innovation Economics, 4, 2, pp. 5-13.

HAMDOUCH, A., MOULAERT, F. (2006), Knowledge Infrastructure, Innovation Dynamics, and Knowledge Creation/diffusion/ accumulation Processes: A Comparative Institutional Perspective, Innovation, 19, 1, pp. 25-50.

KLINE, S., ROSENBER, G.(1986), An overview of innovation, In: Landau, R., Rosenberg, N. (eds), The Positive Sum Strategy: Harnessing Technology for Economic Growth, Washington, DC, National Academy Press, pp. 275-305.

KONSTI-LAAKSO, S., PIHKALA, T., KRAUS, S. (2012), Faciliting SME Innovation Capability through Business Networking, Creativity and Innovation Management, 21, 1, pp. 93-104.

LAPERCHE, B. (2012), General presentation innovation processes: why institutions matter, Journal of Innovation Economics, 9, 1, pp. 3-11.

OBJECT MANAGEMENT (OMG) (2012), OMG Systems Modeling Language (OMG SysML TM) - Version 1.2. Available on: http://www.omg.org/spec/SysML/1.3/PDF/.

OBJECT MANAGEMENT GROUP (OMG) (2011a), OMG Unified Modeling Language TM (OMG UML) - Version 2.4.1 1. Available on: http://www.omg.org/spec/UML/2.4.1/.

OBJECT MANAGEMENT GROUP (OMG) (2011b), Business Process Model and Notation (BPMN) - Version 2.0. Available on: http://www.omg.org/spec/BPMN/2.0.

RESCHER, N. (1978), Scientific Progress: A philosophical essay on the economics of research in natural science, Oxford, UK, Basil Blackwell.

RESCHER, N. (2013), How Modeling Can Go Wrong: Some Cautions and Caveats on the Use of Models, Philosophy \& Technology, 26, 1, pp. 75-80.

RESCHER, N., URQUHART, A. (1971), Temporal Logic, New York, Springer Verlag.

SAMARA, E., GEORGIADIS, P., BAKOUROS, I. (2012), The impact of innovation policies on the performance of national innovation systems: A system dynamics analysis, Technovation, 32, 9-10, pp. 624-638.

SIMON, H. (1997), The Sciences of the Artificial, Cambridge, MA, MIT Press, third edition.

THE OPEN GROUP ARCHITECTURE FRAMEWORK (TOGAF) (2013), http://www.opengroup.org/togaf/. 
UZUNIDIS, D., BOUTILLIER, S. (2012), Globalization of R\&D and network innovation: what do we learn from the evolutionist theory? Journal of Innovation Economics, 10, 2, pp. 23-52.

WOOLTHUIS, R-K., LANKHUIZEN, M., GILSING, V. (2005), A system failure framework for innovation policy design, Technovation, 25, 6, pp. 609-619. 